\title{
Public Service Bureaucratic Reform: A Case Study on Coordination in One Stop Services (KPTSP) in Takalar Regency
}

\author{
${ }^{1}$ Gita Susanti, ${ }^{2}$ Rifani \\ ${ }^{12}$ Departement of Public Administration, Faculty of Social and Political Sciences, Universitas \\ Hasanuddin, Makassar, Indonesia, 90245 \\ E-mail: ${ }^{1}$ gitasusanti65@gmail.com; ${ }^{2}$ rifani@gmail.gmail.com
}

Received: 28 Oktober 2020; Revised: 27 November 2020; Accepted: 25 Desember 2020

\begin{abstract}
Bureaucratic services tend not to improve their performance and carry out reforms. Service users are often faced with so many problems when they are dealing with bureaucracy. The purpose of this study is to describe the reform of the Public Service Bureaucracy in terms of coordination in One Stop Services (KPTSP) in Takalar Regency. In this study, a qualitative approach was used. The type of research used in this research is descriptive research type. The results showed that hierarchical mechanisms in the form of a structured flow of coordination and power need each other to establish cooperation within organizational units. The market mechanism shows that the change in the bureaucracy from services to revenue to provide income for the region through the collection of fees. Licensing and providing incentives can improve the performance of One-Stop Services, Takalar District has a network mechanism that is interrelated and needs each other, this can be seen from the requirements given by the Service Agency One-Stop Integrated Takalar Regency that asks for recommendations from related Regional Work Units (SKPD).
\end{abstract}

Keywords: Public Service; Bureaucratic Reform; Coordiantion

Link DOI : http://dx.doi.org/10.31314/pjia.9.2.125-131.2020

\section{INTRODUCTION}

The reform process has brought a paradigm shift from government to governance. Revitalization and repositioning of local government institutions have been carried out to initiate the decentralization process (regional autonomy) as part of the process towards governance. Decentralization to optimize government functions, including services, regulation, and empowerment formulated in public policy, and oriented to the needs of the community. Optimization of government functions can be realized if officials are sensitive and responsive to new opportunities and challenges, are able to make breakthroughs, think creatively and innovatively, have futuristic and systemic anticipatory insights to minimize risks and optimize potential resources (Moll \& Hoque, 2000).

Decentralization and regional autonomy policies are based on the values of democratization, empowerment, and service (Haris, 2005; Gudina, 2007; Yakub, 2018). The regional government in regional autonomy has the best discretion and decision-making within its authority to develop all its potential in supporting the quality of public services it provides to the community. However, so far what has happened is that the implementation of decentralization is still limited as an effort to increase PAD. Commitment to improving local community conditions in a real and systemic manner through improving the performance of the 
bureaucracy and public services is still relatively low.

We can see this from the face of the bureaucratic services that have tended to not improve their performance and carry out reforms. Service users are often faced with so many problems when they are dealing with bureaucracy. Both prices, additional time and ethics as well as service procedures which tend to be very complex and long so that it is very difficult to be properly reviewed by the community as service users who must be served well (Insani, 2020).

Therefore, bureaucratic reform is a demand for the reform era that has begun to be rolled out to improve state services to its citizens. The word reform comes from the Latin term formare, which means to form, comes from the word forma which means to form. In accordance with the original word, the term reform has several meanings. First, a change for the better or an improvement; second, correction of errors, deviations, or violations; third, an action for revolutionaries. As a term used in relation to the government or the State, the term reform can mean placing a new and improved form or condition; to improve the shape of the state, or bring a change from bad to good so that welfare as an objective can be achieved. (Delfitri, 2005).

Many complaints and criticisms have also been voiced by the public to government agencies that provide services related to the conditions of service to the community, both at the central and regional levels. Case by case in various service sectors occurs, while the practice of public services is still felt giddy and only fulfills the demands of duties and regulations.

Seeing how complex the problems that occur in the practice of providing public services in accordance with the principles of good governance, efforts to improve the quality of public services in Indonesia of course require changes that are holistic, comprehensive and touch all dimensions of problems faced by the service bureaucracy (Junaedi, 2020). Policy reforms in the field of public service delivery must be carried out comprehensively, so as not to be sectorally fragmented and without logical coherence, and carried out according to the level of development and the needs of the community. Reform is defined as a radical change for improvement in various fields in a society or a country. The purpose of this study is to describe the reform of the Public Service Bureaucracy in terms of coordination in One Stop Services (KPTSP) in Takalar Regency.

\section{RESEARCHE METHOD}

The location of this research was carried out in Takalar Regency, precisely at the One-Stop Services Office (KPTSP). The location of this research was chosen with the consideration of making it easier for researchers to obtain research data, both primary data and secondary data.

In this study, a qualitative approach was used. The type of research used in this research is descriptive research type. The informants employed in this study were as follows: Head of the Takalar Regency KPTSP Office, Head of the Sub-Section for Administration of the Takalar Regency KPTSP, Head of the Public Complaints Section of the Takalar Regency KPTSP, Head of the Section for Issuance of KPTSP Permits in Takalar Regency, Head of the Facilitation and Investment section of the KPTSP Regency of Takalar and Service User Community. Data analysis activities through data reduction, data presentation, and drawing conclusions. 


\section{RESULTS AND DISCUSSION}

In this study, it will provide an overview of coordination as a component of public service bureaucratic reform at the One-Stop Services Office (KPTSP) in Takalar Regency. It will be described through elements including hierarchical mechanisms, market mechanisms, and network mechanisms. For more details, it can be described as follows:

\section{Hierarchical mechanism}

Hierarchical mechanisms focus on goal setting, allocation of tasks and responsibilities, and control. In the hierarchical mechanism indicator, the positions are arranged in a hierarchical level from top to bottom and to the side. The consequence is that there are positions of superior and subordinate, and some hold greater power and some are smaller. Weber believed that the bureaucracy should operate in a hierarchical system. According to this principle, the organization must be organized in a strict vertical hierarchical system, and communication between workers is limited according to their positions.

The description of the organizational structure of the One-Stop Services Office in Takalar Regency shows that there is a hierarchy that shows a structured flow of coordination and power that requires each other to establish cooperation within organizational units. At the top level of the organization, namely the Head of the Agency who has the most power as well as responsibilities and duties in coordinating the planning for issuance of permits, public complaints, facilitation, and development of the investment.

From the results of the interview above, it shows that a hierarchical position can be determined through the competence, work performance, and ranks position and are provided with training requirements for that position.

The rank of the group in the organization is a matter that is taken into account considering the rank and class obtained provides an overview of the experience and competencies possessed in a career as a civil servant in the hierarchy level at the One-Stop Services Office of Takalar Regency which shows the highest position, namely the Tk 1 (IV / b) coach. namely, the Head of the Agency occupies the highest position in the organizational hierarchy.

It can be said that a description of the hierarchical level that focuses on goals and arrangements that can be considered from the level of the position is filled by employees who are competent, experienced, and have work performance in their fields, this process is in line with the increase in the class of a civil servant who can later fill the hierarchical position. which is arranged in a structured manner shows that the whole process has a mechanism at the goal and arrangement and hierarchical levels in the One-Stop Services (PTSP) Office of Takalar Regency showing a structured flow of coordination and power that need each other to establish cooperation within organizational units.

\section{Market Mechanism}

The market dimension of the bureaucratic public service organization is monopolistic controlled by the government which adapts to the principle of adopting market mechanisms in the public service bureaucracy (marketization) (Islam \& Farazmand, 2008). This can be elaborated through the mechanisms applied to the financing provided in licensing services and incentives for performance improvement. 
In licensing services at the One-Stop Integrated Service Office, Takalar Regency requires financing in licensing services. As in the TDP and SIUP services, from the results of the interview above, it can be seen that there is financing for all kinds of permits, including the administration of TDP and SIUP.

Financing for several services including TDP and SIUP has manufacturing costs including TDP which costs 100,000 for saving and loan cooperative and individuals, 250,000 for $\mathrm{CV}$, and PT for 500,000. then for foreign capital financing (PMA) of 1,000,000. Then for the SIUP of medium-sized businesses is subject to fees of 100,000 and large businesses of 250,000, while Micro and Small Enterprises are free of charge. Furthermore, the financing provided for various types of services at the PTSP Office of Takalar Regency is intended as an effort to increase local revenue. This can be explained through an interview with the Head of PTSP Permit Issuance Office of Takalar Regency.

From the results of the interview above, it can be illustrated that the revenue-generating market mechanism can be implemented through licensing services in terms of financing which aims to increase the revenue of Regional Original Revenue (PAD). In addition, this study also describes the market mechanism from different aspects, namely, the market mechanism is one of the coordination instruments that focus on creating incentives for increased performance (incentives as the main resource). This means that the incentives provided to employees of the Takalar One-Stop Integrated Service encourage increased bureaucratic performance.

Based on the results of the interview above, it shows that the incentives are based on echelon and non-echelon levels. In addition, the provision of incentives can be divided into material forms that can be given in the form of money or social security, while in non-material forms, it can be given in the form of awarding services, awards, and promotions (promotion or position), as well as the provision of special equipment in the workspace.

In this case, the provision of incentives by the Takalar One-Stop Integrated Service Office, namely the additional income obtained through additional income allowances received by employees, can actually spur employee performance and increase productivity at work so that they can provide good service.

It is undeniable that material incentives or additional income are things that can spur employee motivation (Robbins, 2006) stating that money may not be the only motivator, but it is difficult to argue that money is not motivational. In order for money to motivate the performance of an individual must be met the conditions that money must be considered important by the individual, money is prepared as a direct reward for performance, the amount of money offered for that performance is prepared meaningfully by the individual. Meanwhile, according to Dessler (2000) rewards in the form of money can damage intrinsically, but it does not mean that rewards in the form of money are not used at all. Rewards in the form of money will be more effective when applied as part of comprehensive management such as improving quality and productivity.

From a series of explanations that have been described regarding the market mechanism, it shows changes in the bureaucracy from services towards income 
to provide income for the region through collecting fees. Public permits are monopolistic in nature besides that from other aspects the market mechanism is directed to generate motivation for individuals to increase work productivity in every routine work that is carried out. this happens because of the incentive support provided.

\section{Network Mechanism}

Network mechanisms focus on forming common knowledge, common values, and common strategies among partners (trust as the main source) of the active process of building and managing productive relationships. A wide and strong network of relationships, both personal and organizational.

Service bureaucracy in the One-Stop Services Office has a wide network of relationships. From the results of the interview above, it can be seen that the PTSP (One-Stop Integrated Service) Agency collaborates with various institutions, one of which is explained is the collaboration with BKPM (the Investment Coordinating Board) and Lemsaneg (the National Crypto Agency), it is hoped that through this collaboration, licensing services are fast, simple, transparent, and integrated, to make it easier for investors.

In addition, at the level of agencies at the service or agency level, there is also a network mechanism that cannot be separated. From the results of the interview above, it can be seen that the services at the One-Stop Services Office in Takalar Regency have a network mechanism that is interrelated and requires each other, this can be seen from the requirements given by the Takalar Regency One-Stop Integrated Service Agency which asked for recommendations from the relevant explanations, it illustrates that there are cooperation and networks that are built in the service bureaucracy at the One-Stop Services Office in Takalar Regency. Partnerships can be formed by meeting several requirements in which there are two or more parties, have the same vision in achieving goals, have an agreement, need each other (Waddock, 1988; Glasbergen et al., 2007). This network mechanism shows that the Takalar Regency One-Stop Integrated Service Agency cannot carry out services autonomously but requires cooperation from other agencies, this is related to the recommended procedures requested from an agency or Regional Work Unit (SKPD) where the applicant is located. This is certainly a form of agreement that exists between agencies so that it is inseparable from coordination involving parties related to licensing services.

Coordination as a component of public service bureaucratic reform at the One-Stop Integrated Service Office (KPTSP) in Takalar Regency is illustrated in this study through elements including hierarchical mechanisms, market mechanisms, and network mechanisms. From the research results, it is illustrated that a series of structured coordination and power flows need each other to establish cooperation within organizational units. At the top level of the organization, namely the Head of the Agency who has the most power as well as responsibilities and duties in coordinating the planning for issuance of permits, public complaints, facilitation, and development of the investment.

Hierarchical levels that focus on goals and arrangements that can be considered from the level of position are filled by employees who are competent, experienced and have work performance in their fields, this proceeds along with the , ISSN: 2301-573X (Print), ISSN: 2581-2084 
increase in the class of a civil servant who later can fill a hierarchical position that is structured to show the overall In this process, there is a mechanism at the goals and arrangements and hierarchical levels in the PTSP Office of Takalar Regency, showing the flow of coordination and power in a structured manner that requires each other to establish cooperation within organizational units.

This study describes the market mechanism showing changes in the bureaucracy from services to income to provide income to the regions through levying fees. Public permits are monopolistic in nature, apart from other aspects, the market mechanism is directed to generate motivation for individuals to increase work productivity in every routine work done in this case. occurs because of the incentive support provided.

In addition, the One-Stop Integrated Service, Takalar Regency, has a network mechanism that is interrelated and requires each other. This can be seen from the requirements given by the Takalar Regency One-Stop Integrated Service Agency which asked for recommendations from the relevant SKPD. The three mechanisms described in the coordination component present a hierarchical structure level that supports the implementation of tasks, cooperation networks between agencies, and monopolistic market mechanisms controlled by the government in the aspect of determining incentives and revenues so comprehensively it can be explained that coordination is bringing the relationship between different activities. or incident and improvement of the suitability of tasks and affairs to achieve the appropriate goal. (Ongaro, 2009).

Then the flow of coordination and power in a structured manner requires each other to establish cooperation in organizational units (hierarchical mechanisms). the coordination that focuses on creating incentives to improve performance (incentives as the main resource) that gives rise to incentives and local revenues are partly described in this study in terms of the coordination component. Then the work specialization component is the division of work fields, namely the degree to which tasks in the organization are broken down into separate jobs according to the needs, education, experience, and skills possessed by employees (Brusoni, 2005; Robbins, 2006). In the research results, it was found that there was a greater division of duties in one of the divisions/sections, namely the Facilitation and Investment Development section. Specialization refers to the extent to which organizations tend to focus on one or a limited number of tasks, not overcoming a set of tasks (Ongaro, 2009).

From various explanations regarding bureaucratic reform in the One-Stop Service Office of Takalar Regency, it shows that there is a change in the bureaucracy, there is coordination that is built through hierarchical and network mechanisms, but there are still deficiencies in specializations that still have a division of tasks which experiences gaps in the division/section division in the Service Office One-Stop Integrated Takalar Regency, namely there is a division of one division with a larger portion of tasks.

\section{CLOSING}

\section{Conclusion}

Bureaucratic reform at the One-Stop Service Office in Takalar District shows a hierarchical mechanism in the form of structured coordination and power flow that requires each other to establish cooperation within organizational units. 
The market mechanism shows a change in the bureaucracy from services towards revenue to provide income for the regions through collecting fees.

\section{Suggestion}

Licensing and providing incentives can improve employee performance and the description of the network mechanism shows that there is coordination involving agencies related to licensing services.

\section{REFERENCES}

Brusoni, S. (2005). The limits to specialization: problem solving and coordination in 'modular networks'. Organization Studies, 26(12), 18851907.

Delfitri, Y. (2005). Reformasi Birokrasi di Mahkamah Agung. Jakarta: Universitas Krisnadwipayana.

Dessler, G. (2000). Human Resource Management Prentice-Hall Inc. New Jersey USA, 370-372.

Glasbergen, P., Biermann, F., \& Mol, A. P. (Eds.). (2007). Partnerships, governance and sustainable development: Reflections on theory and practice. Edward Elgar Publishing.

Gudina, M. (2007). Ethnicity, democratisation and decentralization in Ethiopia: The case of Oromia. Eastern Africa Social Science Research Review, 23(1), 81-106.

Haris, S. (2005). Desentralisasi dan otonomi daerah: desentralisasi, demokratisasi \& akuntabilitas pemerintahan daerah. Yayasan Obor Indonesia.

Insani, N. (2020). Apparatus Professionalism and Public Service
Ethics. Journal La Sociale, 1(1), 2528.

Islam, M. R., \& Farazmand, A. (2008). Perceptions of civil servants toward privatization and development: A new exploratory study. Public Organization Review, 8(1), 37-52.

Junaedi, J. (2020). Implementation of Good Corporate Governance (GCG) in the Field of Securing Plantation Assets. Journal La Sociale, 1(3), 5-9.

Moll, J., \& Hoque, Z. (2000). Rationality, new public management and changes in management control systems: a case study of managing change in an Australian local government setting. In Interdisciplinary Perspectives on Accounting (IPA) 2000 Conference, Manchester.

Ongaro, E. (2009). Public management reform and modernization: Trajectories of administrative change in Italy, France, Greece, Portugal and Spain. Edward Elgar Publishing.

Robbins, S. P. (2006). Perilaku Organisasi. Jakarta: PT Indeks Kelompok Gramedia.

Waddock, S. A. (1988). Building successful social partnerships. MIT Sloan Management Review, 29(4), 17.

Yakub, A., Ghani, A. B. A., \& Anwar, M. S. I. (2018). Urgency of Political Decentralization and Regional Autonomy in Indonesia: Local Perspectives. Journal of International Studies, 14, 141-150. 